\title{
DAYA HASIL BEBERAPA KULTIVAR PADI GOGO LOKAL ASAL KABUPATEN TOJO UNA-UNA DAN SIGI
}

\section{Yields of Various Local Upland Rice Cultivars Originated From Tojo Una-Una and Sigi Districts}

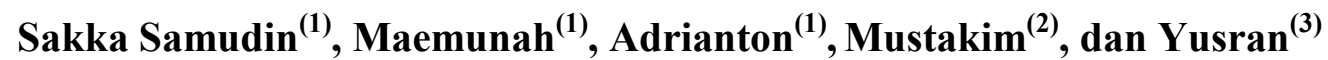 \\ 1) Dosen Fakultas Pertanian Universitas Tadulako \\ 2) Program Studi Agroteknologi Fakultas Pertanian Universitas Tadulako \\ 3) Laboran Fakultas Pertanian Universitas Tadulako \\ Email:sakka01@yahoo.com, maemunah.tadulako2@gmail.com, \\ adrianton1978@gmail.com, takimcfe@gmail.com, yusran_untad@yahoo.co.id
}

Submit: 15 Juli 2020, Revised: 6 Agustus 2020, Accepted: Agustus 2020

\begin{abstract}
The development of upland rice is one alternative to increase national rice production. Evaluation of local upland rice yields is very important to be done considering that upland rice has different adaptability. The purpose of this study was to test and determine the first year yield of local upland rice originating from Pipikoro and Ampana and planted in Kalama valley of Tamarenja which located at 180-250 meters above sea level with latitude LS 00026 '51.5 "and BT 119049'50.6" in Sindue sub-district of Donggala regency. This research was arranged using a Randomized Block Design with 10 cultivars as genotypic treatments, i.e. jahara, kalendeng, pulu tau leru, uva buya, dongan, wangan, tako, Delima, buncaili and uva which were repeated four times so that there were 40 experimental units. The observed variables included: plant height, leaf length, number of tillers, number of productive plants, panicle length, age of harvest, number of seeds per panicle, weight of 1000 seeds and production. Jahara and Dongan cultivars are found to have high yields.
\end{abstract}

Keywords: Ampana; Kulawi; Upland Rice and Yield.

\begin{abstract}
ABSTRAK
Pengembangan padi gogo merupakan salah satu alternatif untuk meningkatkan produksi padi nasional. Evaluasi daya hasil padi gogo lokal sangat penting untuk dilakukan mengingat padi gogo memiliki daya adaptasi yang berbeda-beda. Tujuan dari penelitian ini ialah untuk mengkaji dan mengetahui daya hasil padi gogo lokal asal Pipikoro dan Ampana yang ditanam di Tamarenja (Lembah Kalama) pada tahun pertama. Penelitiaan ini dilaksanakan di Desa Tamarenja (Lembah Kalama), dengan ketinggian tempat 180-250 Mdpl denganletaklintang LS 00 26'51.5" serta BT $119^{\circ} 49^{\prime} 50.6^{\prime}$ Kecamatan Sindue, Kabupaten Donggala. Waktu penelitian dimulai dari bulan April sampai Oktober 2017. Penelitian ini disusun menggunakan Rancangan Acak Kelompok dengan 10 kultivar sebagai perlakuan genotip yaitu: kultivar jahara, kalendeng, pulu tau leru, uva buya, dongan, wangga, tako, delima, buncaili dan uva yang diulang sebanyak empat kali sehingga terdapat 40 unit percobaan. Peubah yang diamati meliputi: tinggi tanaman, panjang daun, jumlah anakan, jumlah akan
\end{abstract}


produktif, panjang malai, umur panen, jumlah biji per malai, bobot 1000 biji dan produksi. Hasil penelitian menunjukkan bahwa kultivar Jahara dan Dongan menghasilkan daya hasil yang tinggi.

Kata Kunci: Ampana; Daya Hasil; Kulawi dan Padi Gogo.

\section{PENDAHULUAN}

Kebutuhan beras sebagai bahan pangan utama Indonesia terus meningkat seiring dengan pertumbuhan penduduk yang terus meningkat dari tahun ketahun. Sebagian besar produksi padi nasional masih berfokus pada lahan sawah sedangkan lahan sawah setiap tahunnya telah mengalami penyusutan dikarenakan alih fungsi lahan, (Zhang et al., 2013; Deng et al., 2014); Sutaryo dan Pamungkas 2019).

Pengembangan dan perluasan areal budidaya padi gogo merupakan alternatif untuk meningkatkan produksi pangan nasional, karena perluasan lahan sawah semakin sulit dilakukan. Padi jenis gogo banyak memiliki keunggulan diantaranya dapat tumbuh di lahan marginal tanpa harus membutuhkan sebuah teknologi yang super mewah, (Ichsan dkk. 2017; Putra dkk. 2014).

Verietas lokal memiliki berbagai macam jenis yang tersebar diseluruh dataran Indonesia dan tidak semua varietas lokal memiliki produksi yang sama. Metode eksplorasi dan seleksi merupakan cara yang efektif untuk memperoleh varietas lokal yang berproduksi tinggi sehingga dapat memenuhi kebutuhan pangan masyarakat indonesia, (Suhartini. 2010; Zen dan Syarif. 2013; Sarwanto dkk. 2018).

Tujuan dari penelitian ini ialah untuk mengkaji dan mengetahui daya hasil padi gogo lokal asal Pipikoro dan Ampana yang ditanam di Tamarenja (Lembah Kalama) pada tahun pertama.

\section{METODE PENELITIAN}

Penelitiaan ini dilaksanakan di Desa Tamarenja (Lembah Kalama), dengan ketinggian tempat 180-250 mdpl dengan letak lintang LS $00^{\circ} 26^{\prime} 51.5^{\prime \prime}$ serta BT
11949'50.6' Kecamatan Sindue, Kabupaten Donggala. Waktu penelitian dimulai dari bulan April sampai Oktober 2017.

Penelitian ini disusun menggunakan Rancangan Acak Kelompok (RAK) dengan 10 kultivar sebagai perlakuan yang diulang sebanyak empat kali sehingga terdapat 40 unit percobaan. Pengambilan sampel dilakukan dengan cara mengambil empat tanaman yang berada dibagian tengah bedengan.

Tabel 1. Kultivar Yang Digunakan Sebagai Perlakuan

\begin{tabular}{|l|l|}
\hline \multicolumn{1}{|c|}{ Kultivar/Genotipe } & \multicolumn{1}{c|}{ Asal } \\
\hline Jahara & Ampana \\
\hline Kalendeng & Ampana \\
\hline Pulu tau leru & Pipikoro \\
\hline Uva buya & Ampana \\
\hline Dongan & Ampana \\
\hline Wangga & Pipikoro \\
\hline Tako & Ampana \\
\hline Delima & Ampana \\
\hline Buncaili & Pipikoro \\
\hline Uva & Ampana \\
\hline
\end{tabular}

Penelitian diawali dengan melakukan sanitasi lahan dari sisa-sisa tanaman dan gulma, selanjutnya membuat bedengan sebanyak 40 bedengan dengan panjang $210 \mathrm{~cm}$ dan lebar $120 \mathrm{~cm}$ serta jarak antar bedangan ialah $40 \mathrm{~cm}$, selanjutnya melakukan penanaman dengan jarak tanam $30 \times 30 \mathrm{~cm}$ menggunakan benih yang sebelumnya telah direndam selama 12 jam, selanjutnya melakukan perawatan dengan meliputi penyiangan gulma, pemupukan dengan menggunakan pupuk NPK mutiara (16:16:16) dengan dosis $300 \mathrm{~kg} / \mathrm{ha}$, selanjutnya melakukan pemanenan dengan kriteria gabah yang telah mengalami perubahan warna (matang fisiologi).

Peubah yang diamati meliputi: tinggi tanaman $(\mathrm{cm})$, panjang daun $(\mathrm{cm})$, jumlah anakan, jumlah anakan produktif, 
panjang malai $(\mathrm{cm})$, umur panen (hari), jumlah biji per malai yang diamati pada fase generatif, serta peubah amatan bobot 1000 biji (gram) dan produksi (ton/ha) dihitung setalah Pemanen dan dilakukan proses pengeringan hingga kadar air 14\%.

Data yang diperoleh dianalisis menggunakan analisis ovarian (Anova) dan di uji lanjut dengan menggunakan uji Beda Nyata Jujur (BNJ) pada taraf 1\%.

\section{HASIL DAN PEMBAHASAN}

Hasil uji BNJ taraf 1\% menunjukkan bahwa kultivar pulu tau leru menghasilkan nilai rata-rata tinggi tanaman paling rendah namun tidak berbeda dengan kultivar dongan dan buncaili. Kultivar tako menghasilkan nilai rata-rata tinggi tanaman tertinggi namun tidak berbeda dengan kultivar jahara (tabel 2).

Tanaman yang pendek mempunyai keunggulan tidak mudah rebah dan mudah untuk dipanen, sedangkan tanaman yang tinggi mempunyai kelemahan mudah roboh dan sulit untuk dipanen. Kultivar pulu tau leru, dongan, dan buncaili merupakan kultivar yang memiliki tinggi terbaik karena tidak mudah rebah dan mudah untuk dijangkau, (Mafaza dkk. 2019; Jambhulkar, Bose. 2014).
Hasil uji BNJ taraf 1\% menunjukkan bahwa kultivar wangga menghasilkan daun terpendek namun tidak berbeda dengan kultivar jahara, pulu tau leru, tako dan buncaili, sedangkan kultivar delima menghasilakan nilai rata-rata panjang daun terpanjang dibanding kultivar yang lain, (tabel 2).

Karakter panjang daun sangat erat hubungannya dengan proses fotosintesis, respirasi, dan transpirasi pada tanaman. Proses fotosintesis dapat menghasilkan karbohidrat dan oksigen $\left(\mathrm{O}_{2}\right)$ dengan memanfaatkan $\mathrm{CO}_{2}$, air, dan cahaya matahari yang ada di alam, dimana karbohidrat akan digunakan dan dimanfaatkan tanaman untuk kelangsungan hidupnya, (Hüve et al. 2019; Susanto dkk. 2020; Tombesi et al. 2019).

Tanaman yang memiliki daun yang panjang dapat mengakibatkan proses penguapan air dari jaringan tanaman (transpirasi) yang lebih tinggi dibanding tanaman yang memiliki daun yang pendek, karena daun yang panjang mempunyai stomata yang lebih banyak dibanding daun yang pendek dan akan mengakibatkan tanaman libih cepat layu dan membutuhkan air yang lebih banyak, (Munawaroh dkk. 2016; Kumarathunge et al. 2019; Rahayu dan Harjoso. 2010).

Tabel 2. Hasil Uji Lanjut Peubah Amatan

\begin{tabular}{lcccccc}
\hline \multirow{2}{*}{ Perlakuan } & \multicolumn{5}{c}{ Nilai Rata-Rata Peubah yang Di Amati } \\
\cline { 2 - 7 } Jahara & TT & Pd & JA & JAP & PM & JBPM \\
Kalendeng & $174,63^{\text {de }}$ & $57,70^{\mathrm{a}}$ & $5,25^{\text {de }}$ & $5,00^{\mathrm{d}}$ & $32,70^{\mathrm{b}}$ & $154,00^{\mathrm{ab}}$ \\
Pulu Tau Leru & $155,23^{\mathrm{bc}}$ & $67,80^{\mathrm{b}}$ & $4,25^{\mathrm{bc}}$ & $3,50^{\mathrm{ab}}$ & $34,60^{\mathrm{c}}$ & $210,00^{\mathrm{c}}$ \\
Uva Buya & $137,54^{\mathrm{a}}$ & $52,48^{\mathrm{a}}$ & $3,31^{\mathrm{a}}$ & $3,25^{\mathrm{a}}$ & $26,85^{\mathrm{a}}$ & $237,29^{\mathrm{d}}$ \\
Dongan & $164,05^{\mathrm{cd}}$ & $65,73^{\mathrm{b}}$ & $6,75^{\mathrm{f}}$ & $6,00^{\mathrm{e}}$ & $31,55^{\mathrm{b}}$ & $205,75^{\mathrm{c}}$ \\
Wangga & $147,28^{\mathrm{a}}$ & $66,30^{\mathrm{b}}$ & $3,50^{\mathrm{ab}}$ & $3,50^{\mathrm{ab}}$ & $33,05^{\mathrm{bc}}$ & $139,75^{\mathrm{a}}$ \\
Tako & $151,44^{\mathrm{b}}$ & $51,00^{\mathrm{a}}$ & $2,69^{\mathrm{a}}$ & $2,69^{\mathrm{a}}$ & $28,43^{\mathrm{a}}$ & $185,17^{\mathrm{b}}$ \\
Delima & $176,48^{\mathrm{e}}$ & $58,48^{\mathrm{ab}}$ & $4,50^{\text {cd }}$ & $4,00^{\mathrm{bc}}$ & $29,50^{\mathrm{ab}}$ & $243,75^{\mathrm{d}}$ \\
Buncaili & $167,98^{\mathrm{d}}$ & $78,43^{\mathrm{c}}$ & $4,50^{\text {cd }}$ & $4,50^{\mathrm{cd}}$ & $38,55^{\mathrm{d}}$ & $260,00^{\mathrm{d}}$ \\
Uva & $147,52^{\mathrm{ab}}$ & $57,53^{\mathrm{a}}$ & $3,48^{\mathrm{a}}$ & $3,48^{\mathrm{a}}$ & $26,27^{\mathrm{a}}$ & $192,53^{\mathrm{bc}}$ \\
\hline \multicolumn{1}{c}{ BNJ 1\% } & $168,90^{\mathrm{d}}$ & $67,45^{\mathrm{b}}$ & $5,75^{\mathrm{e}}$ & $5,25^{\mathrm{de}}$ & $26,15^{\mathrm{a}}$ & $224,50^{\mathrm{cd}}$ \\
\hline
\end{tabular}

Keterangan: Angka Yang Diikuti Huruf Yang Sama Tidak Menunjukan Perbedaan Dan Angka Yang Diikuti Huruf Yang Berbeda Menunjukkan Perbedaan. 


\begin{tabular}{|c|c|c|c|}
\hline \multirow{2}{*}{ Perlakuan } & \multicolumn{3}{|c|}{ Nilai Rata-Rata Peubah Amatan } \\
\hline & UP & Bobot 1000 Biji & Produksi \\
\hline Jahara & $140,00^{\mathrm{c}}$ & $32,48^{\mathrm{f}}$ & $3,66^{\mathrm{f}}$ \\
\hline Kalendeng & $126,00^{\mathrm{ab}}$ & $31,00^{\mathrm{e}}$ & $3,44^{\mathrm{ef}}$ \\
\hline Pulu Tau Leru & $131,50^{\mathrm{b}}$ & $27,24^{\mathrm{c}}$ & $1,54^{\mathrm{b}}$ \\
\hline Uva Buya & $140,00^{\mathrm{c}}$ & $30,25^{\mathrm{de}}$ & $3,36^{\mathrm{e}}$ \\
\hline Dongan & $119,00^{\mathrm{a}}$ & $31,65^{\mathrm{ef}}$ & $3,52^{\mathrm{f}}$ \\
\hline Wangga & $136,25^{\mathrm{bc}}$ & $33,18^{\mathrm{f}}$ & $1,03^{\mathrm{a}}$ \\
\hline Tako & $126,00^{\mathrm{ab}}$ & $24,08^{\mathrm{a}}$ & $2,67^{\mathrm{c}}$ \\
\hline Delima & $140,00^{\mathrm{c}}$ & $28,43^{\mathrm{cd}}$ & $3,16^{\mathrm{de}}$ \\
\hline Buncaili & $124,25^{\mathrm{a}}$ & $24,19^{\mathrm{a}}$ & $1,38^{\mathrm{b}}$ \\
\hline Uva & $126,00^{\mathrm{ab}}$ & $26,48^{b c}$ & $2,94^{\mathrm{cd}}$ \\
\hline BNJ 1\% & 10,69 & 2,06 & $\mathbf{0 , 3 0}$ \\
\hline
\end{tabular}

Keterangan: Angka Yang Diikuti Huruf Yang Sama Tidak Menunjukan Perbedaan Dan Angka Yang Diikuti Huruf Yang Berbeda Menunjukkan Perbedaan

Hasil uji BNJ pada taraf $1 \%$ menunjukkan kultivar wangga menghasilkan jumlah anakan dan anakan produktif yang lebih sedikit namun tidak berbeda dengan kultivar pulu tau leru, dongan dan buncaili. Kultivar uva buya menghasilkan nilai ratarata jumlah anakan dan anakan produktif yang lebih banyak namun tidak berbeda dengan kultivar uva.

Jumlah anakan dan anakan produktif merupakan salah satu sifat yang dapat mempengaruhi produksi tanaman padi, semakin banyak anakan dan anakan produktif maka berpotensi menghasilkan produksi yang lebih banyak, (Sutaryo. 2012).

Hasil uji BNJ taraf $1 \%$ menunjukkan kultivar uva menghasilkan panjang malai terpendek namun tidak berbeda dengan kultivar buncaili, tako, wangga, dan pulu tau leru, sedangkan kultivar dongan menghasilkan jumlah biji permalai yang lebih sedikit namun tidak berbeda dengan kultivar jahara.

Kultivar delima memiliki panjang malai terpanjang dibanding kultivar yang lain, sedangkan kultivar tako mengkasilkan jumlah biji permalai yang lebih banyak namun tidak berbeda dengan kultivar uva, delima, dan pulu tau leru.

Panjang malai dapat menjadi indikator dalam menentukan peningkatan produksi apabila diikuti dengan peningkatan jumlah biji permalai. Kultivar yang memiliki panjang malai terpanjang dan jumlah biji per malai yang lebih banyak yaitu kultivar delima, hal ini mengindikasikan bahwa kultivar delima berpotensi menghasilkan produksi yang lebih banyak dibanding kultivar yang lain, (Supriadin dkk. 2013; Sarwanto dkk. 2018).

Hasil uji BNJ pada taraf 1\% menunjukkan bahwa kultivar jahara menghasilkan umur panen yang lebih lama di banding kultivar yang lain namun tidak berbeda nyata dengan kultivar uva buya, wangga, dan delima. Kultivar dongan menghasilkan umur panen yang lebih cepat di banding kultivar yang lain namun tidak berbeda nyata dengan kultivar kalendeng, tako, buncaili dan uva.

Tanaman yang memiliki umur panen yang cepat atau berumur genjah berpeluang dipanen dua sampai tiga kali dalam setahun. Kultivar dongan, uva, buncaili, tako dan kalendeng merupakan Tanaman yang berumur genjah dan karakter ini yang diinginkan oleh petani dan pemulia karena bisa dipanen berkalikali dalam setahun, (Barmawi dkk. 2013).

Hasil uji BNJ taraf $1 \%$ menunjukkan bahwa kultivar tako menghasilakan bobot 1000 biji yang lebih ringan namun tidak berbeda dengan kultivar buncaili, sedangkan kultivar wangga menghasilkan bobot 1000 biji yang lebih berat namun tidak berbeda dengan kultivar dongan, dan jahara (González et al., 2016; Kokalj et al., 2019; Parvaneh et al., 2019).

Karakter bobot 1000 biji merupakan karakter yang mengindikasikan produktifitas 
dan mutu benih, semakin berat bobot 1000 biji maka semakin meningkat mutu benih dan mutu produksi tanaman (Mondal et al., 2018; Farouk and Abdul Qados, 2018; Khozaei et al., 2020). Bobot 1000 biji juga menjadi salah satu faktor penentu produksi tanaman, dengan meningkatnya bobot 1000 biji maka produksi tanaman juga meningkat, (Syukur dkk. 2010; Adimiharja dkk. 2017; Mustakim et al. 2019).

Hasil uji BNJ taraf 1\% menunjukkan bahwa kultivar wangga menghasilkan nilai rata-rata produksi yang lebih rendah dibanding kultivar yang lain, sedangkan kultivar jahara menghasilkan nilai rata-rata produksi yang lebih tinggi namun tidak berbeda nyata dengan kultivar kalendeng dan dongan (Cui et al., 2020; Oculi et al., 2020; Wang et al., 2020).

Hasil penelitian yang diperoleh bahwa terdapat keberagaman produksi dari beberapa kultivar yang digunakan, dimana produksi berkisar antara 1,03 ton/ha hingga 3,66 ton/ha. Keberagaman produksi diakibatkan karena adanya perbedaan gen yang mengendalikan produksi dimasingmasing kultivar, (Mustakim et al. 2019).

Perbedaan produksi juga dipengaruhi oleh kemapuan suatu kultivar untuk beradaptasi dengan lingkungannya karena tidak semua kultivar memiliki daya adaptasi yang sama. Kultivar yang digunakan merupakan kultivar lokal asal kecamatan Kulawi dan Ampana yang ditanam di Desa Tamarenja (Lembah Kalama). Kultivar jahara, kalendeng dan dongan merupakan kultivar yang berdaya hasil tinggi, hal ini dapat diduga ketiga kultivar tersebut memiliki daya adaptasi yang luas di banding kultivar yang lainnya, (Sutaryo dan Pamungkas. 2019; Purbokurniawan dkk. 2014).

Produksi yang tinggi juga merupakan karakter utama yang menjadi acuan para petani dalam membudidayakan tanaman padi, sebab dengan produksi yang tinggi kebutuhan pangan masyarakat dapat terpenuhi (Peng et al., 2020; Sadanandom and Murchie, 2020; Xiong et al., 2020). Kultivar jahara, kalendeng dan dongan dapat menjadi pilihan budidaya padi 187 ladang (gogo) sebab dapat menghasilkan produksi yang cukup tinggi, (Mawaddah dkk. 2018; Nugraha dkk. 2019).

\section{KESIMPULAN}

Kultivar Jahara dan Dongan menghasilkan daya hasil yang tinggi.

\section{DAFTAR PUSTAKA}

Adimiharja, J., J. Kartahadimaja., dan E. E. Syuriani (2017). Karakter Agronomi dan Potensi Hasil Galur Tanaman Padi (Oryza sativa L.) yang Terbentuk Pada Generasi Ketiga (F3). Jurnal Penelitian Pertanian Terapan. 17(1): 33-39.

Barmawi, M., A. Yushardi., dan N. Sa'diyah (2013). Daya Waris Dan Harapan Kemajuan Seleksi Karakter Agronomi Kedelai Generasi F2 Hasil Persilangan Antara Yellow Bean Dan Taichung. Agrotek Tropika. 1(1): 20-24.

Cui, L., Bandillo, N., Wang, Y., Ohm, J.-B., Chen, B., Rao, J., 2020. Functionality and structure of yellow pea protein isolate as affected by cultivars and extraction $\mathrm{pH}$. Food Hydrocolloids 108, 106008. https://doi.org/10.1016/j.foodhyd.20 20.106008

Deng, C., Teng, X., Peng, X., Zhang, B., 2014. Effects of simulated puddling intensity and pre-drying on shrinkage capacity of a paddy soil under long-term fertilization. Soil and Tillage Research 140, 135-143. https://doi.org/10.1016/j.still.2014.0 $\underline{2.012}$

Farouk, S., Abdul Qados, A.M.S., 2018. Enhancing seed quality and productivity as well as physioanatomical responses of pea plants by folic acid and/or hydrogen peroxide application. Scientia Horticulturae 240, 29-37. https://doi.org/10.1016/j.scienta.201 8.05 .049 
González, M., Salazar, E., Cabrera, S., Olea, P., Carrasco, B., 2016. Analysis of anthocyanin biosynthesis genes expression profiles in contrasting cultivars of Japanese plum (Prunus salicina L.) during fruit development. Gene Expression Patterns 21, 54-62.

https://doi.org/10.1016/j.gep.2016.06 $\underline{.005}$

Hüve, K., I. Bichele., H. Kaldmäe., B. Rasulov., F. Valladares., and Ü. Niinemets (2019). Responses of Aspen Leaves to Heatflecks: Both Damaging and Non-Damaging Rapid Temperature Excursions Reduce Photosynthesis. Plants, 8(6), 145.

Ichsan, C. N., Bakhtiar., Efendi., dan Sabaruddin (2017). Karakteristik Hasil Varietas/Genotipe Padi (Oriza sativa L.) Terpilih di Lahan Tadah Hujan. Prosiding Seminar Biotik.

Jambhulkar, N. N., and L. K. Bose (2014). Genetic variability and association of yield attributing traits with grain yield in upland rice. Genetika, 46(3): 831-838.

Khozaei, M., Kamgar Haghighi, A.A., Zand Parsa, S., Sepaskhah, A.R., Razzaghi, F., Yousefabadi, V., Emam, Y., 2020. Evaluation of direct seeding and transplanting in sugar beet for water productivity, yield and quality under different irrigation regimes and planting densities. Agricultural Water Management 238, 106230.

https://doi.org/10.1016/j.agwat.2020. 106230

Kokalj, D., Zlatić, E., Cigić, B., Kobav, M.B., Vidrih, R., 2019. Postharvest flavonol and anthocyanin accumulation in three apple cultivars in response to blue-light-emitting diode light. Scientia Horticulturae 257, 108711.

https://doi.org/10.1016/j.scienta.201 9.108711
Kumarathunge, D. P., J. E. Drake., M. G. Tjoelker., R. López., S. Pfautsch., A.Vårhammar., and B. E. Medlyn (2019). The temperature optima for tree seedling photosynthesis and growth depend on water inputs. Global Change Biology. gcb.14975

Mafaza, V., H. Handoko., dan A. Adiredjo (2019). Keragaman Genetik Karakter Morfologi Beberapa Genotip Padi Merah (Oryza sativa L.) pada Fase Vegetatif dan Generatif. Jurnal Produksi Tanama. 6(12)

Mawaddah., B. S. Purwoko., I. S. Dewi, dan D. Wirnas (2018). Karakterisasi Sifat Agronomi Tanaman Padi Beras Merah Dihaploid Berpotensi Hasil Tinggi Diperoleh melalui Kultur Antera. J. Agron Indonesia. 46(2): 126-132

Mondal, P., de Alcântara Mendes, R., Jonathan, M.P., Biswas, J.K., Murugan, K., Sarkar, S.K., 2018. Seasonal assessment of trace element contamination in intertidal sediments of the meso-macrotidal Hooghly (Ganges) River Estuary with a note on mercury speciation. Marine Pollution Bulletin 127, 117130.

https://doi.org/10.1016/j.marpolbul.2 017.11 .041

Munawaroh, L., E. Sulistyono., dan I. Lubis (2016). Karakter Morfologi dan Fisiologi yang Berkaitan dengan Efisiensi Pemakaian Air pada Beberapa Varietas Padi Gogo. Jurnal Agronomi Indonesia. 44(1).

Mustakim., S. Samudin., dan Maemunah. 2019. Genetic Diversity, Heritability And Correlation Between Local Cultivars Of Upland Rice. Agroland: The Agricultural Sciences Journal. 6(1): 20-26.

Nugraha, G. T., S. Samudin., dan Nursalam (2019). Pertumbuhan dan Hasil Beberapa Kultivar Padi Gogo Lokal Pada Jenis Pupuk Kandang yang 
Berbeda. J. Agrotekbis. 7(2): 155163).

Nurazizah, A., Hairmansis, A., dan Damanhuri, D. (2019). Uji Daya Hasil dan Pendugaan Parameter Genetik Karakter Agronomi Genotipe Padi Gogo (Oryza sativa L.). Jurnal Produksi Tanaman. 7(12).

Oculi, J., Bua, B., Ocwa, A., 2020. Reactions of pineapple cultivars to pineapple heart rot disease in central Uganda. Crop Protection 135, 105213. https://doi.org/10.1016/j.cropro. 2020 $\underline{.105213}$

Parvaneh, T., Abedi, B., Davarynejad, G.H., Ganji Moghadam, E., 2019. Enzyme activity, phenolic and flavonoid compounds in leaves of Iranian red flesh apple cultivars grown on different rootstocks. Scientia Horticulturae 246, 862-870. https://doi.org/10.1016/j.scienta.201 $\underline{8.11 .034}$

Peng, C., Tong, H., Shen, C., Sun, L., Yuan, P., He, M., Shi, J., 2020. Bioavailability and translocation of metal oxide nanoparticles in the soilrice plant system. Science of The Total Environment 713, 136662. https://doi.org/10.1016/j.scitotenv.20 20.136662

Purbokurniawan., B. S. Purwoko., D. Wirnas., dan I. S. Dewi (2014). Potensi dan Stabilitas Hasil, Serta Adaptabilitas Galur-Galur Padi Gogo Tipe Baru Hasil Kultur Antera. J. Agron indonesia. 42(1): 9-16.

Putra, O. D., S. Samudin., dan I. Lakani (2014). Karakterisasi Genotip Padi Lokal Kamba Asal Dataran Lore. Agrotekbis 2(2) : 146-154.

Rahayu, A. Y., dan T. Harjoso (2010) Karakter Agronomis dan Fisiologi Padi Gogo yang di Tanam Pada Media Tanah Bersekam pada Kondisi Air di Bawah Kapasitas Lapang. Akta Agrosia. 13(1): 40-49.
Sarwanto., S. Samudin., dan A. Ete (2018). Karakterisasi Beberapa Kultivar Padi Gogo Lokal. Agrotekbis 6(2): 274284.

Suhartini, T. 2010. Keragaman Karakter Morfologis Plasma nuthfa Spesies Padi Liar (Oryza spp.). Buletin Plasma Nuthfa. 16(1)

Supriadin., A. Ete., dan U. Made (2013). Karakterisasi Genotip Padi Gogo Lokal Asal Kabupaten Banggai. J. Agrotekbis. 1(5): 443-450.

Susanto, A., A. E. Prasetyo., H. Priwiratama., dan M. Syarovi (2020). Laju fotosintesis pada tanaman kelapa sawit terinfeksi karat daun Cephaleuros virescen. Jurnal Fitopatologi Indonesia, 16(1), 21-29

Sutaryo, B. (2012). Ekspresi Daya Hasil Dan Beberapa Karakter Agronomi Enam Padi Hibrida Indica Di Lahan Sawah Berpengairan Teknis. Ilmu Pertanian. 15(2): 19-29

Sutaryo, B., dan D. H, Pamungkas (2019). Penampilan Hasil Gabah Dan Komponen Agronomi Padi Hibrida Di Godean. Jurnal Ilmiah Agroust, 1(1), 106-115.

Syukur, M., S. Sujiprihati., R. Yunianti., dan D. A. Kusumah (2010). Evaluasi Daya Hasil Cabai Hibrida dan Daya Adaptasinya di Empat Lokasi dalam Dua Tahun. Agron Indonesia 38(1): 43-51.

Tombesi, S., I. Cincera., T. Frioni., V. Ughini., M. Gatti., A. Palliotti., and S. Poni (2019). Relationship among night temperature, carbohydrate translocation and inhibition of grapevine leaf photosynthesis. Environmental and Experimental Botany, 157: 293-298.

Sadanandom, A., Murchie, E.H., 2020. A Tropical Plant with Friends in Cold Places: The Formation of the UK Rice Research Community. Trends in Plant Science 25, 421-422. 
https://doi.org/10.1016/j.tplants.2020 .02 .014

Wang, B., Gao, Y., Yuan, X., Xiong, S., Feng, X., 2020. From species to cultivar: Soybean cultivar recognition using joint leaf image patterns by multiscale sliding chord matching. Biosystems Engineering 194, 99111.

https://doi.org/10.1016/j.biosystemse ng.2020.03.019

Xiong, H., Hou, F., Li, H., Wang, H., 2020. Does rice farming shape audit quality: Evidence from signing auditors level analysis. Economic Modelling 91, 403-420. https://doi.org/10.1016/j.econmod.20 20.06.013

Zen, S., dan A. A. Syarif (2013) Peluang Perbaikan Varietas Lokal Padi Gogo Pasaman Barat. Buletin Plasma Nutfah. 19(1).

Zhang, Z.B., Peng, X., Wang, L.L., Zhao, Q.G., Lin, H., 2013. Temporal changes in shrinkage behavior of two paddy soils under alternative flooding and drying cycles and its consequence on percolation. Geoderma 192, 12-20.

https://doi.org/10.1016/j.geoderma.2 $\underline{012.08 .009}$ 